Policy and Practice Brief

\title{
Farming in the time of pandemic: Small farms demonstrate flexibility, innovation, and hope
}

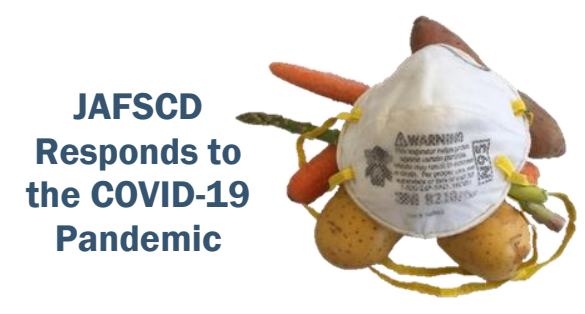

\author{
Nora E. White* \\ University of Washington Tacoma and Hercules Farm
}

Submitted October 4, 2020 / Accepted October 4, 2020 / Published online March 19, 2021

Citation: White, N. E. (2021). Farming in the time of pandemic: Small farms demonstrate

flexibility, innovation, and hope. Journal of Agriculture, Food Systems, and Community Development, 10(2), 247-249. https://doi.org/10.5304/jafscd.2021.102.008

Copyright $(2021$ by the Author. Published by the Lyson Center for Civic Agriculture and Food Systems. Open access under CC-BY license.

\section{Abstract}

The COVID-19 pandemic affected small farmers in the 2020 growing season as they navigated how to maintain their businesses while meeting health and safety concerns. Through interviews with Ellis Creek Farm and Riverbend Ranch, two small farms in Thurston County, Washington, I explore the impacts of the pandemic, the need for flexibility, and the unique challenges and adaptations these farms employed early in the pandemic to stay afloat. These stories are valuable community assets because hearing directly from farmers about their experiences, challenges, and plans is a way to gain insight and learn. In the face of crises such as a pandemic or climate change, a changed food system that includes small farms is necessary for community resiliency.

\section{Keywords}

Small Farms, COVD-19, Pandemic, Adaptation, Local Food, Resiliency, Agriculture, Community Supported Agriculture, Direct to Consumer, Food System

* Nora E. White, MAIS Graduate Student, University of Washington Tacoma; Farmer, Hercules Farm; newhite@uw.edu

\section{Author Note}

This is an abbreviated version of a student oral history project conducted in spring 2020 regarding workers in the time of pandemic. The full version, interview transcripts, and images of interviewees are published online with the Tacoma Community History Project. The link can be found at the end of this essay. 
$I^{n}$ n spring 2020, through my work as an agricultural service provider and farmer, I started hearing from local farmers who were gearing up for a season unlike any other due to COVID-19. When I spoke with farmers Joel Baranick and Ann Petricola of Ellis Creek Farm and Kevin Jensen of Riverbend Ranch in May 2020, they shared their experiences of watching two things happen simultaneously: their usual markets were slipping away as wholesale accounts were cancelled, and their inboxes were filling up with requests to buy direct.

The United States saw a trend toward direct-market sales in 2020. Articles with titles like Organic farmers fill national food system holes revealed by COVID-19 (Polito, 2020), Community Supported Agriculture Is Surging Amid the Pandemic (Ricker \& Kardas-Nelson, 2020), and COVID-19 Sparks a Rebirth of the Local Farm Movement (Hiller, 2020) started appearing regularly and illustrated a common theme: consumers with financial means were looking locally for food that felt safe and reliable. The usual avenues of procurement no longer felt secure.

COVID-19 has exposed the United States' food system as incredibly vulnerable and inequitable: meat packing plants have had to close (Kludt, 2020), migrant farm workers have been denied assistance and health coverage even while acknowledged as essential and vulnerable (Jordan, 2020), and the use of food banks and assistance programs has surged along with unemployment (Abou-Sabe, Romo, McFadden, \& Longoria, 2020). The closed loop of commerce offered by small farms has at least partially supplemented this system at a local level as small farms have the potential to be more adaptable, flexible, and open to market changes. Ellis Creek Farm and Riverbend Ranch exemplify this.

Ann and Joel of Ellis Creek Farm grow and sell microgreens and specialty salad mix wholesale in Pierce and Thurston counties (south of Seattle). This crop focus has been successful, and they were anticipating another season of business growth. But in March 2020, as non-essential businesses shuttered and usual buyers cancelled their orders, Ellis Creek Farm had to make a choice about what this season would look like. They started a weekly CSA delivery of microgreens and salad. Throughout this season, Ann and Joel have stayed flexible as phases of re-opening take effect. Joel explained their flexibility plan:

When we were seeing this all develop, we were doing our field plant half the size of normal. ... [But] we went back to a full field plantings. ... And I think we're just going to try to sell it or donate it. ... We don't want to be caught flat-footed if restaurants open and then we're not able to sell to them.

Since my conversation with Ann and Joel, they have had some wholesale accounts come back online, but flexibility remains key. In Ann's words:

I guess we're just trying to figure it out ... how to adopt and make changes quickly enough to be able to keep up with the changes that we don't know are coming. ... We're persistent, so we're just gonna keep doing what we're doing.

At Riverbend Ranch, Kevin is a fourth-generation rancher working with his family to raise beef, pork, and Christmas trees. Since adding a wedding venue, there are many moving parts and constant work. Riverbend Ranch's experience of COVID-19 has been twofold: beef and pork shares are sold out through the year, while their wedding venue is nearly a total loss. Unlike Ellis Creek Farm, which saw an immediate change in its sales model, the interest in buying meat has been more ordinary, if unprecedented in scale.

By the end of March/first part of April the gates opened up ... right about the time that first slaughterhouse back East closed down because of COVID. ... And it's just been kind of a 
whirlwind from there. ... I don't know how many emails I've got today. I'm scared to look ... it's been challenging ... we're sold out right now [of beef and pork], until January/February '21.

While meat sales have been steady, new customers mean extra work in providing education for those unfamiliar with what cuts look like from a pasture-raised animal. Additionally, the future of the wedding venue and Christmas tree stand-high-value parts of their business-are uncertain for 2021. Kevin shared that there are "way too many unknowns to make decisions" and that they must take a long-range view of the future for this year:

You gotta plan to lose it, and then gain it where you can and just keep going forward. ... Anybody that's farmed for any number of years ... it's just another day. ... You see that in ag. There's always something trying to destroy you. ... But you gotta have thick skin and just keep looking ahead.

Highlighting, upholding, and remembering the flexibility that these farms demonstrate is necessary in the face of uncertainty. In the months since I did these interviews, the pandemic continues to shine a harsh light on systems of economic inequality in the United States-food access and agricultural support among them. Small farms such as these show a resiliency and adaptability that is essential for the continued health of our communities. As Kevin, Ann, and Joel exemplify, farmers are willing to put it all on the line because they believe in the work of growing and raising our food. They believe in feeding our communities. We have an obligation to learn from COVID-19 and to anticipate a changed food system in the future.

A full version of this essay along with interview transcripts and photos of the farmers can be found on the Tacoma Community History Project website: https://cdm16786.contentdm.oclc.org/digital/ collection/tacomacomm/id/680/rec/20

\section{References}

Abou-Sabe, K., Romo, C., McFadden, C., \& Longoria J. (2020, April 8). COVID-19 crisis heaps pressure on nation's food banks. NBC News. Retrieved from

https://www.nbcnews.com/news/us-news/covid-19-crisis-heaps-pressure-nation-s-food-banks-n1178731

Hiller, S. (2020, May 21). COVID-19 sparks a rebirth of the local farm movement. Yes! Magazine. Retrieved from https://www.yesmagazine.org/environment/2020/05/21/coronavirus-food-local-farm-movement

Jordan, M. (2020, April 2). Farmworkers, mostly undocumented, become 'essential' during pandemic. The New York Times. Retrieved from https://www.nytimes.com/2020/04/02/us/coronavirus-undocumented-immigrant-farmworkers-agriculture.html

Kludt, A. (2020, May 11). How the pandemic exposed the cracks in our industrial meat system. Eater. Retrieved from https://www.eater.com/2020/5/11/21254684/how-the-pandemic-exposed-the-cracks-in-our-industrial-meat-system

Polito, R. (2020, April 28). Organic farmers fill national food system holes revealed by COVID-19. New Hope Network. Retrieved from https://www.newhope.com/food-and-beverage/organic-farmers-fill-national-food-system-holes-revealed-covid-19

Ricker, H., \& Kardas-Nelson M. (2020, April 9). Community supported agriculture is surging amid the pandemic [Blog post]. Civil Eats. Retrieved from https://civileats.com/2020/04/09/community-supported-agriculture-is-surging-amid-the-pandemic/ 